\title{
REVISTAS PREDATÓRIAS: RECONHECER PARA NÃO ERRAR
}

DOI: 10.5327/Z1414-4425201800040001

Publicações predatórias miram estudiosos experientes, que contribuem para a construção da credibilidade da revista e, assim, também atraem outros autores desavisados, que, por pressão acadêmica de publicações, não percebem a natureza nefasta dessas revistas que publicam em tempo recorde ${ }^{1}$.

0 advento do acesso (AC) aberto foi um avanço para a academia sem precedentes na história da ciência no mundo. Tornou a divulgação do conhecimento rápida e contribuiu para a expansão, em nível internacional, da mais recente produção ${ }^{2}$. Na esteira do sucesso desse modelo, os editores predatórios cresceram publicando revistas tendenciosas, com o objetivo de explorar o AC em que os autores pagam taxas. Seus artigos são aceitos e publicados em curto espaço de tempo, colocando em descrédito o sistema de avaliação peer review e mesmo a editoração do manuscrito, a qual, ao que parece, não passa por revisão, uma vez que são publicadas com erros ortográficos e gramaticais.

A sedução aos autores é feita por convites enviados por e-mails, em que são apresentadas as qualidades do periódico, tais como indexação, fator de impacto e título da revista muito semelhante a publicações consagradas - , gerando confiança aos autores. Os convites são elogiosos, propõem facilidades de publicação, como o aceite e a divulgação rápida, $\mathrm{e}$ atendem à necessidade de publicar dos pesquisadores, que sofrem pressão das universidades para terem artigos em boas revistas, de alto impacto. Assim, os acadêmicos incautos, em início de carreira, de países em desenvolvimento, se tornam vulneráveis às oportunidades oferecidas pelos editores predatórios e passam a ser alvos da estratégia maliciosa de captação de artigos.

Por outro lado, a ausência de tática de reconhecimento de publicações predatórias e de discussão da problemática quanto a esse gênero de literatura "científica" aumenta a fragilidade dos pesquisadores à publicação. Caso houvesse um debate mais aprofundado entre pesquisadores, poderia ser posta a questão da qualidade de artigos, pois esses trabalhos, quando divulgados em meios duvidosos, embora possam ser boas pesquisas, carregam consigo o estigma do lugar de publicação.

Ademais, as revistas predatórias não têm clara sua política de preservação digital. O site existe durante um curto período, deixando os autores sem saber onde encontrar seus artigos, o que torna muito difícil recuperar a informação algum tempo depois da publicação. Tal fato pode causar dano irreparável para os pesquisadores, os quais têm a memória de sua produção perdida ${ }^{3}$.

A Academia Internacional de Editores de Enfermagem (INANE) mantém um diretório de revistas de enfermagem confiáveis, o qual é atualizado frequentemente, com a finalidade de auxiliar os pesquisadores de nossa profissão. Constitui-se em importante site de busca para conferir possíveis espaços de publicação ${ }^{4}$.

Joel Rolim Mancia [

Doutor em Enfermagem pela Universidade Federal de Santa Catarina (UFSC), Florianópolis, Brasil. Professor da Universidade do Vale do Rio dos Sinos (UNISINOS), Porto Alegre, Brasil.

\section{REFERÊNCIAS}

1. Mancia JR, Felli VEA. Prática de publicação "predatória". Enferm Foco. 2013;4(3-4):145. https://doi.org/10.21675/2357-707X.2013. v4.n3/4.535

2. Beall J. Medical publishing triage - chronicling predatory open access publishers. Ann Med Surg. 2013;2(2):47-9. https://doi.org/10.1016/ S2049-0801(13)70035-9
3. Beall J. Predatory publishers are corrupting open acess. Nature. 2012;489(7415):179. https://doi.org/10.1038/489179a

4. Oermann MH, Nicoll LH, Chinn PL, Ashton KS, Conklin JL, Edie AH, et al. Quality of articles published in predatory nursing journals. Nursing Outlook. 2018;66(1):4-10. https://doi.org/10.1016/j. outlook.2017.05.005 